\title{
GENOMIC INTEGRITY EVALUATION IN SPERM OF CHOROMYTILUS CHORUS (MOLINA, 1782) BY COMET ASSAY
}

\section{EVALUACION DE INTEGRIDAD GENOMICA EN ESPERMATOZOIDES DE CHOROMYTILUS CHORUS (MOLINA, 1782) MEDIANTE ENSAYO COMETA}

\author{
Fabiola Lafarga-De la Cruz ${ }^{1,2}$, Myriam Valenzuela-Bustamante ${ }^{1}$, Enrique Dupré3, Miguel A. \\ del Río-Portilla ${ }^{4} \&$ Cristián Gallardo-Escárate ${ }^{1}$
}

\begin{abstract}
'Departamento de Oceanografía, Facultad de Ciencias Naturales y Oceanográficas, Centro de Biotecnología, Universidad de Concepción. Casilla 160-C, Concepción, Chile.

E-mail address: cristian.gallardo@udec.cl (C. Gallardo-Escárate)

${ }^{2}$ Facultad de Ciencias Agronómicas, Universidad de Chile. Santa Rosa 11315, La Pintana, Santiago, Chile.

${ }^{3}$ Departamento de Biología Marina, Facultad de Ciencias del Mar, Universidad Católica del Norte. Casilla 117, Coquimbo, Chile.

${ }^{4}$ Departamento de Acuicultura, División de Oceanología, Centro de Investigación Científica y de Educación Superior de Ensenada. Km 107 Carretera Tijuana-Ensenada, Baja California, México.
\end{abstract}

\begin{abstract}
The comet assays or single cell gel electrophoresis is a simple, rapid, relatively inexpensive and very sensitive method that has been recently widely used to evaluate genomic integrity (or DNA damage) in aquatic animals exposed to diverse physical and chemical agents. However, the accuracy to evaluate comets assay has been the major obstacle in order to determine specific damage undergone cellular stress. The aim of this study was to evaluate DNA fragmentation in sperm cells based in fluorescence image analysis. The species used was the giant mussel Choromytilus chorus. The in vitro experiments were carried out through oxidative stress with five hydrogen peroxide concentrations $(0,50,100,500$ and $1000 \mu \mathrm{M})$. To evaluate DNA damage two groups of parameters were used: (1) Morphological comet parameters as tail length, nuclear diameter (head) and tail moment, and (2) Quantification of DNA strand breaks grade by fluorescence image analysis. The sperm DNA damage was possitively correlated with the morphological parameters, as they were exposed to an increasing dose range of $\mathrm{H}_{2} \mathrm{O}_{2}$ and negatively correlated with nuclear diameter. Additionally, fluorescence analysis showed that fragment sizes and the fluorescence intensity could be identified and related the level of DNA damage independently the intercellular variation of DNA strand breaks. The large fragment sizes decrease with $\mathrm{H}_{2} \mathrm{O}_{2}$ doses, while medium and small fragments increase in treatments with highest peroxide concentration. This study supported future research to examine comet assay conjugated with molecular approaches, especially in reference to integrate FISH to evaluate if the DNA fragmentation includes specific genes.
\end{abstract}

KEYWORDS: Single cell gel electrophoresis, DNA damage, image analysis.

\section{RESUMEN}

El ensayo cometa o gel de electroforesis de única célula es un procedimiento sencillo, rápido, relativamente barato y un método muy sensible para evaluar la integridad del genoma (ADN o daños) en los animales acuáticos expuestos a diversos agentes físicos y químicos. Sin embargo, la precisión para evaluar los ensayos cometas han sido el principal obstáculo para determinar el daño específico sufrido por estrés celular. El objetivo de este estudio fue evaluar la fragmentación del ADN en espermatozoides basado en análisis de imágenes fluorescente. La especie utilizada fue el choro zapato, Choromytilus chorus. Los experimentos in vitro se llevaron a cabo por estrés oxidativo con cinco concentraciones de peróxido de hidrógeno $(0,50,100,500$ y $1000 \mu \mathrm{M})$. Para evaluar el daño del ADN se utilizaron dos grupos de parámetros: (1) parámetros morfológicos de los cometas como la longitud de la cola, el diámetro nuclear (cabeza) y el tail moment, y (2) Cuantificación de la fragmentación de ADN mediante análisis de imagen fluorescentes. El daño del ADN en el esperma se 
Genomic integrity in sperm of Choromytilus chorus: LAFARGA, F. ETAL.

correlacionó positivamente con los parámetros morfológicos, a medida que fue expuesto a una mayor dosis de $\mathrm{H}_{2} \mathrm{O}_{2}$ y negativamente correlacionado con el diámetro nuclear. Además, el análisis de fluorescencia mostró que los tamaños de los fragmentos y la intensidad de fluorescencia pueden ser relacionados con el nivel de daño en el ADN independiente de la variación intercelular. Los fragmentos grandes disminuyen con la dosis de $\mathrm{H}_{2} \mathrm{O}_{2}$, mientras que los medianos y pequeños aumentan a mayor concentración de peróxido. Este estudio apoya futuras investigaciones para examinar el ensayo cometa en conjunto con enfoques moleculares, especialmente en referencia a la integración de FISH para evaluar si la fragmentación del ADN incluye genes específicos.

PalABRAS ClaVes: Electroforesis de gel de única célula, daño en el ADN, análisis de imágenes.

\section{INTRODUCTION}

The potential application of the comet assay as a method to evaluate both in vivo and in vitro effects of DNA damage in aquatic animals has been well established by numerous studies and recently it has been more frequently used due its advantages (Mitchelmore and Chipman 1998; Cotelle and Férard 1999; Lee and Steinert 2003). As it is a simple, rapid (results could be obtained in a single working day), visual, relative inexpensive and very sensitive method to detect DNA damage at the individual cell level, and it requires only small number of cells to carry out the assay $\left(10^{4}\right)$ and it can be performed on virtually any eukaryotic cell type (Lee and Steinert 2003). The several applications of comet assay have been extend to evaluate DNA repair and apoptosis (halo assay, DNA diffusion asay) and specific DNA lesions (Steinert 1996; Machella et al. 2006). In the comet assay cells are immersed in a low melting point agarose (LMA) matrix, which is packed between layers of normal melting point agarose (NMA) extended in a microscope slice, and treated with a lysis solution to remove cell constituents. After that, nuclear DNA is unwounded under alkaline conditions and fragments resulting from strand breaks can migrate away from the nuclei under an electric field. This migration of DNA fragments appears as a comet tail and can be view by microscopic examination after staining with DNA fluorochromes. Being the degree of damage corresponded with an increase of tail lengths and a reduction of nuclear DNA content (comet head). The DNA migration could be recorded by morphological parameters with the use of microscopy and also helped of specific morphological image analysis software. So, to quantify DNA damage by morphological parameters, initial studies have used measurements as tail length and length:width ratios (Steinert et al. 1998). On the other hand, image analysis system, fluorescent microscope connected to a CCD camera supported by software designed to capture and analyze fluorescence images, had been more useful and timesaving to determine DNA migration in comet assays. Thus, the tail length, tail area, nuclear diameter, nuclear area, and other measures can be determined directly, as well as other morphological comet ratios like \% tail DNA, DNA tail moment [(\% tail DNA $x$ tail length $) / 100]$ and Olive tail moment [(tail mean - head mean) x (\% tail DNA/ 100)] (Lee and Steinert 2003; Dietrich et al. 2005). Additionally, arbitrary and empirical scoring of comets has been reported by categorizing cells into four to five classes based on the extent of migration (Wilson et al. 1998; Machella et al. 2006). However, most of the data cannot be comparable among studies. Furthermore, several papers reviews have been focused in the characteristics of the protocols modifications as well as the strategies to evaluate the DNA strand breaks, being tangible that there are not consensus in the parameters and statistical approach to be used, especially in the morphological measurements limited by the ability to accurately resolve patterns of the DNA disaggregation under fluorescence microscopy.

Comet assay has been performed in a variety of aquatic organisms and especially in mollusks bivalves as clams, mussels, oysters and scallops. Herein, the bivalves have wildly been used to assess DNA damage, focusing mainly in appraising bivalves as biomarkers for an environmental tool (Cotelle \& Férard 1999). Most of these studies were carried out in vivo experiments, and mussels have mainly been the more commonly used organisms (Mitchelmore \& Chipman 1998; Steinert 1999). Due to the purpose of evaluating mussels as a potential pollution indicator organism (sentinel species) the most commonly cell type use to perform the comet assay are gills cells, hemocytes and digestive gland cells 
(Wilson et al. 1998; Steinert 1996, 1999; Cheung et al. 2006; Machella et al. 2006). While in other mollusks cellular tissues as foot, mantle, siphon and style have been used too to perform comet assays (Lee and Steinert 2003). Although preservation of DNA integrity is essential to protect sperm quality and to ensure reproductive success (Dietrich et al. 2005), the usefulness of the comet assay to evaluate sperm quality of mollusks has been having little attention until now (Steinert 1996). Considering all this, our study had has as main aims to compare two evaluation strategies of comet assays: (1) Morphological comet parameters as tail length, nuclear diameter (head) and tail moment, and (2) Quantification of DNA strand breaks grade by fluorescence image analysis. Sperm cells from the giant mussel Choromytilus chorus were used as target cells and hydrogen peroxide as an oxidative stress agent. Herein, we proposed an alternative me thod to assess the level of sperm DNA fragmentation through of fluorescence image analysis.

\section{MATERIALS AND METHODS}

\section{Sample collection}

Mussels Choromytilus chorus were collected from Marine Biology Lab facilities of the University of Concepción, Chile. Sperm cell suspension was obtained by stripping and was preserved in filter seawater $(1 \mu \mathrm{m})$ at low temperature. Cell viability was assessed by sperm motility and the procedure was carried out immediately with a pooled sample of 10 organisms.

\section{Sperm DNA damage induction}

To induce DNA strand breaks (fragmentation), the spermatozoids cells were exposed in vitro to hydrogen peroxide as an oxidative agent. An effective dose range of 50,100, 500 and $1000 \mu \mathrm{M}$ $\mathrm{H}_{2} \mathrm{O}_{2}$ were used according to Wilson et al. (1998) in isolated gill cells of Mytilus edulis. Negative control (without $\mathrm{H}_{2} \mathrm{O}_{2}$ ) sperm cells were incubated with Kenny's salt solution $(0.4 \mathrm{M} \mathrm{NaCl}, 9 \mathrm{mM} \mathrm{KCl}, 0.7$ $\mathrm{mM} \mathrm{K}_{2} \mathrm{HPO}_{4}, 2 \mathrm{mM} \mathrm{NaHCO}$ ). Incubation conditions were $1 \mathrm{~h}$ and $4^{\circ} \mathrm{C}$ under dark conditions.

\subsection{Comet Assay procedure}

The comet assay protocol applied was a modification according to Wilson et al. (1998). Briefly, Kenny's salt solution was also used to wash sperm suspension and to prepare the stock solutions of $\mathrm{H}_{2} \mathrm{O}_{2}$ (treatments). The agarose microgel was prepared using a first layer with $150 \mu \mathrm{L}$ of $1 \%$ normal meeting agarose (NMA), a second layer that contain the treated cells immerse in $75 \mu \mathrm{L}$ of $0.65 \%$ low meeting agarose (LMA) and a third final layer with $75 \mu \mathrm{L}$ of $0.65 \%$ LMA. Two microgels were prepared for each $\mathrm{H}_{2} \mathrm{O}_{2}$ treatment and experiment. Cells were lysed using a salt detergent with $\mathrm{pH} 10(2.5 \mathrm{M} \mathrm{NaCl}, 10$ mM Tris, 0.1 mM EDTA, $1 \%$ Sarcosyl, $1 \%$ Tritón X100 and $10 \%$ DMSO) for $1 \mathrm{~h}$ at $15^{\circ} \mathrm{C}$. DNA unwinding was carried under alkaline buffer $(10 \mathrm{M}$ $\mathrm{NaOH}, 200 \mathrm{mM}$ EDTA, pH 13) for $1 \mathrm{~h}$, and electrophoresis was performed in the same buffer for $20 \mathrm{~min}$ at $24 \mathrm{~V}, 300 \mathrm{~mA}$. After that, microgels were neutralized by washing it three times in 0.4 $\mathrm{mM}$ Tris solution (pH 7.5) and stained with $100 \mu \mathrm{L}$ of $5 \mu \mathrm{M}$ ethidium bromide. The microgels were then recorded using an epiflourescence microscope Nikon Eclipse 80i (filter G-2A, 40x) and images were randomly captured using a digital monochromatic camera Nikon DS-Qi1 and saving in uncompress TIFF format using Image Pro-Plus 4.5 software (MediaCybernetics, Inc.).

Conventional comets parameters analysis Morphological parameters as tail length, total comet area, nuclear diameter and nuclear area were measured directly as pixels units. And tail moment was calculated as percentage of DNA in tail multiplied by tail length and divided by 100 (Lee and Steinert 2003). Percentage of DNA in tail was calculated against the different between total comet area $(100 \%)$ and its corresponding percentage of nuclear area.

Comets parameters analysis by fluorescence image analysis

To evaluate the degree of DNA strand breaks by fluorescence image analysis, two approaches were applied: (i) quantification of DNA fragment sizes according with the fluorescence intensity and evaluated using the percentage of area fragmented and the Integrated Optical Density (IOD $=$ area $\mathrm{x}$ intensity of fluorescence) of large (L), medium (M) and small (S) fragments. The fragment sizes were calculated selecting a specific range of fluorescence intensity using images of gray scale at 8 bits (256 intensity levels). The rages scored were 255-50, 4945 and 44-40 of fluorescence intensity for L, M and S fragments, respectively. (ii) Besides, we use the line 
profiles to obtain a plot of the intensity values of a single line within the comets images. Profiles of fluorescence intensity were then integrated to obtain a measure that shows the fragmentation degree along of the comets. These kinds of information allow quantifying the DNA dispersion around of the comets independently its tail length.

\section{Statistical analyses}

To differ damage among $\mathrm{H}_{2} \mathrm{O}_{2}$ treatments, KruskalWallis no-parametric statistical analysis $(\alpha=0.05)$ was used to assess significant differences among $\mathrm{H}_{2} \mathrm{O}_{2}$ treatments. The statistical analysis was carried out using Statistica 6.0 software (StatSoft, Inc.).

\section{RESULTS}

\section{Comet images}

This study assure that the comet assay protocol suggested by Wilson et al. (1998), developed to evaluate DNA damage in isolated gill cells and hemocytes of M. edulis, can be successfully applied to sperm cells with some little modifications like increasing the alkaline unwinding and electrophoresis times. Comets digital images obtained after an in vitro oxidative stress in hydrogen peroxide are showed in Figure 1. Nuclear diameter of control cells (without $\mathrm{H}_{2} \mathrm{O}_{2}$ ) was statistically different from treated cells. Tails could be seen in cells treated with 50, 100 and $500 \mu \mathrm{M}$

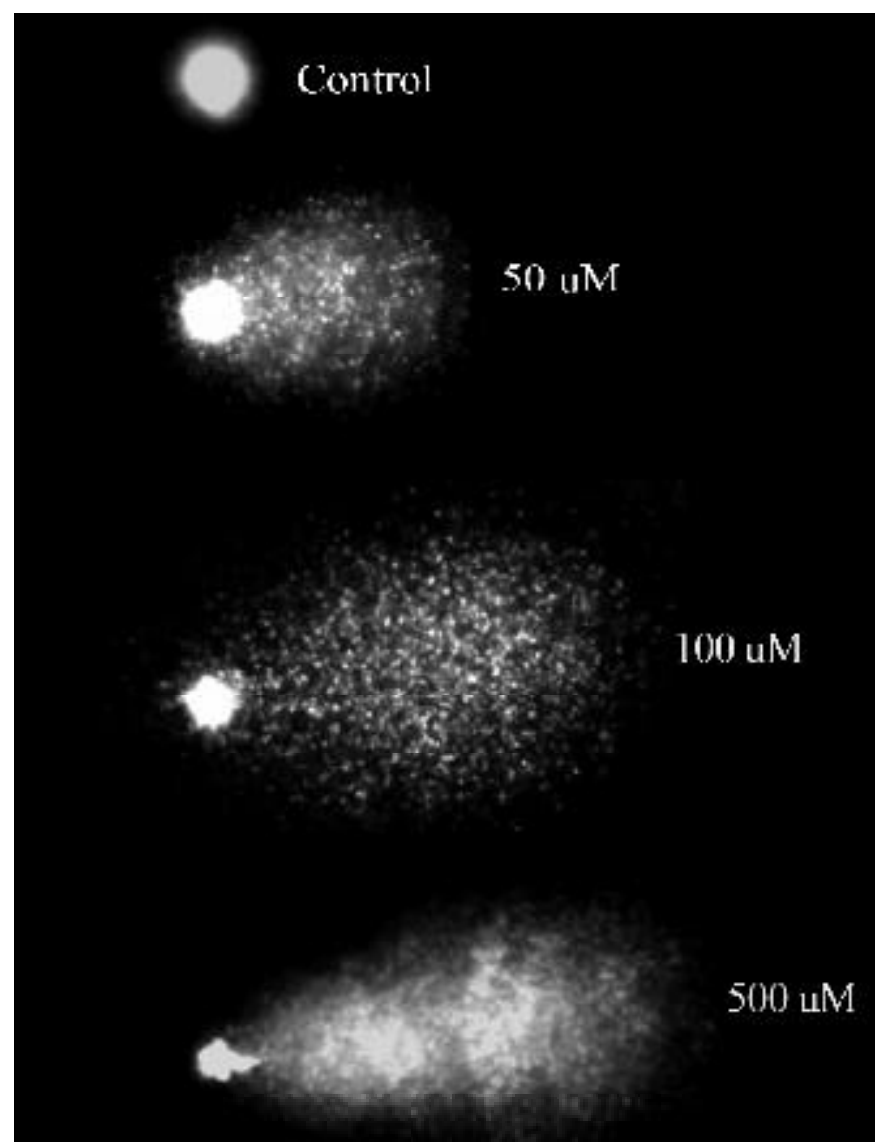

FIGURE 1. DNA strand breaks in spermatozoid nuclei of giant mussel Choromytilus chorus exposed to four concentration of hydrogen peroxide. Negative control (without $\mathrm{H}_{2} \mathrm{O}_{2}$ ).

FIGURA 1. Fragmentación de ADN en núcleos de espermatozoides en choro zapato Choromytilus chorus expuestos a cuatro concentraciones de peróxido de hidrógeno. Control negativo $\left(\sin \mathrm{H}_{2} \mathrm{O}_{2}\right)$. 
$\mathrm{H}_{2} \mathrm{O}_{2}$, but not at $1000 \mu \mathrm{M} \mathrm{H}_{2} \mathrm{O}_{2}$ exposure condition because spermatozoids were hardly damaged at this dose with the tail disconnected from the head of the comets (hedgehog cells).

Evaluation of DNA damage with morphological comet parameters

As expected, microscopical examination corroborates that tail lengths and tail moment parameter were significance different among $\mathrm{H}_{2} \mathrm{O}_{2}$ treatments and directly correlated with the degree of induced DNA damage by the increasing $\mathrm{H}_{2} \mathrm{O}_{2}$ dose. As DNA damage increase tail length and tail moment did (Figs. 2, 3) Statistical differences $(\mathrm{P}<0.05)$ were showed among all treatments of hydrogen peroxide. In fact, no overlap was calculated at both one and two standard error. Furthermore, DNA damage was well established as a significant reduction of nuclear diameter among $\mathrm{H}_{2} \mathrm{O}_{2}$ treatments and was proportional in all treatments with hydrogen peroxide (Fig. 4).

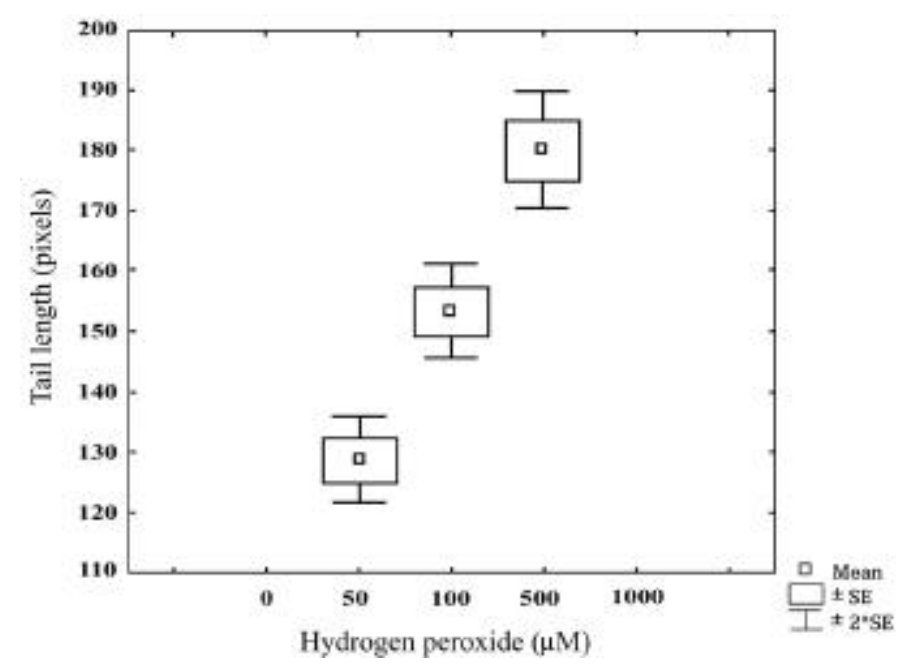

FIGURE 2. Mean ( \pm S.E.) tail length of sperm comets from Choromytilus chorus exposed to 50, 100 and $500 \mu \mathrm{M} \mathrm{H}_{2} \mathrm{O}_{2}$ treatments. Significant differences are indicated by $\mathrm{P}<0.05$.

Figura 2. Media ( \pm D.E) de longitud de cola de cometas en espermatozoides de Choromytilus chorus expuestos a tratamientos de 50,100 y $500 \mu \mathrm{M}$ de $\mathrm{H}_{2} \mathrm{O}_{2}$. Diferencias son indicadas mediante $\mathrm{P}<0.05$.

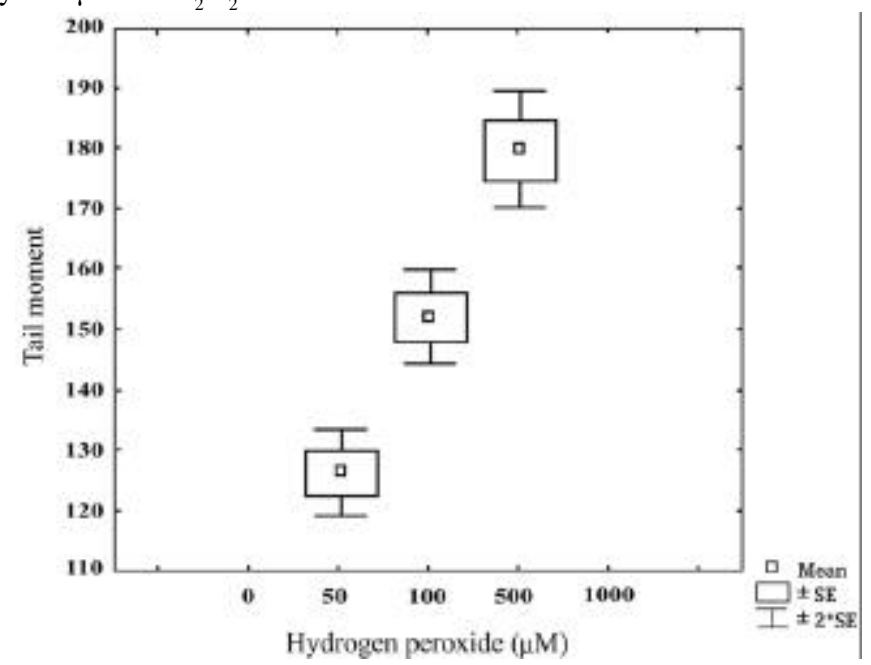

Figure 3. Mean ( \pm S.E.) tail moment of sperm comets from Choromytilus chorus exposed to 50,100 and $500 \mu_{\mathrm{M} \mathrm{H}} \mathrm{O}_{2}$ treatments. Significant differences are indicated by $\mathrm{P}<0.05$.

FigURA 3. Media ( \pm D.E.) tail moment en cometas de espermatozoides de Choromytilus chorus expuestos a tratamientos de 50, 100 y $500 \mu \mathrm{M}$ de $\mathrm{H}_{2} \mathrm{O}_{2}$. Diferencias son indicadas mediante $\mathrm{P}<0.05$. 
Image analysis approach to evaluate comet assay To evaluate the migration of DNA strand breaks in a single nucleus exposed to cellular stress, image analysis was performed to quantify the fluorescence intensity of the fragments. A line profile calculated along the comet showed that the lower treatment $(50 \mu \mathrm{M})$ were more fluorescent in the head comet as well as in the tail. Peroxide concentrations above $100 \mu \mathrm{M}$ shows a decrease in fluorescent intensity in the head comet while that the intensity of the tail at $500 \mu \mathrm{M}$ treatment showed overlapping. The highest fluorescence intensity could be correlated with the co-localization of the larges DNA strand breaks and DNA fragments hightly compacted. Moreover, we could find that the degree of DNA fragmentation trends to increase in acute peroxide treatments and also the line intensity profile through the comets showed more amplitude in high degree of DNA fragmentation (Fig. 5). Additionaly, to evaluate the loss of genome integrity (nuclear DNA content decrease) we performed an analysis according to the DNA strand break sizes by the segmentation in three intensity rages and based in 256 gray levels. The range calculated allow discriminate among large (L), medium (M) and small (S) fragments (255-50, 4945 and 44-40 respectively) according their IOD values. The Figure 6 a shows a digital image of a single comet stained with a DNA fluorochrome. Selected sizes ranges were 255-50, 49-45 and 44-40 for L, M and S fragments, respectively. In addition, intensity fluorescence profiles were obtained, which provide information about tail and nuclear fluorescence intensity and total, tail and nuclear area. DNA damage was also evaluated percentage of large, medium and small fragments and intensity fluorescence profiles were measured and calculated by image analysis.

\section{DISCUSSION}

\section{Comet assay modifications}

To apply the comet assay using mussel spermatozoids as target cell, we modify the alkaline unwinding and electrophoresis time of the protocol proposed by Wilson et al.(1998) applied to mussel gill cells. Increasing timing in unwinding (15vs $60 \mathrm{~min}$ ) and electrophoresis (5 vs $20 \mathrm{~min}$ ) allow us to get a well development comets. Dietrich et al. (2005) establish an unwinding time of 60 min and electrophoresis time of 30 min working with spermatozoa of rainbow trout Oncorhynchus mykiss. We believe that the increase of alkaline unwinding time could be related with the differences between cells types used, specially the degree DNA package.

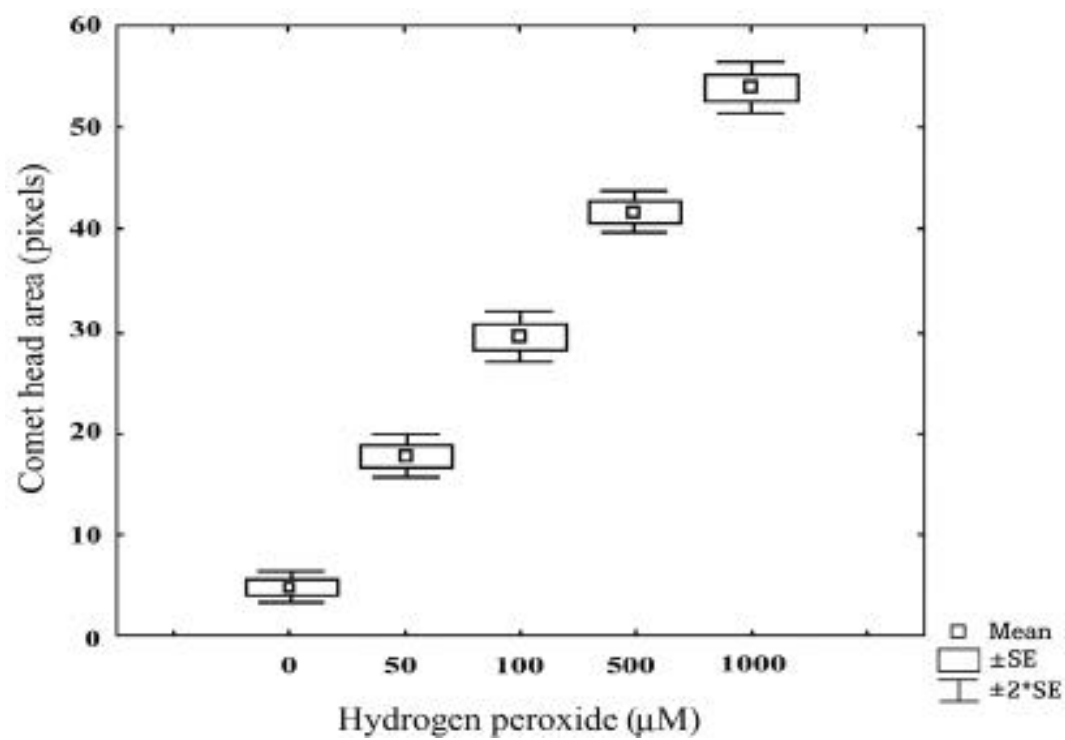

FiguRE 4. Mean ( \pm S.E.) nuclear diameter (head) of sperm comets from Choromytilus chorus exposed to 0, 50, 100, 500 and $1000 \mu \mathrm{M} \mathrm{H}_{2} \mathrm{O}_{2}$ treatments. Significant differences in comparison with the experimental control are indicated by $\mathrm{P}<0.05$.

Figura 4. Media ( \pm D.E.) de diámetro nuclear en cometas de espermatozoides de Choromytilus chorus expuestos a tratamientos de 50,100 y $500 \mu \mathrm{M}$ de $\mathrm{H}_{2} \mathrm{O}_{2}$. Diferencias son indicadas mediante $\mathrm{P}<0.05$. 


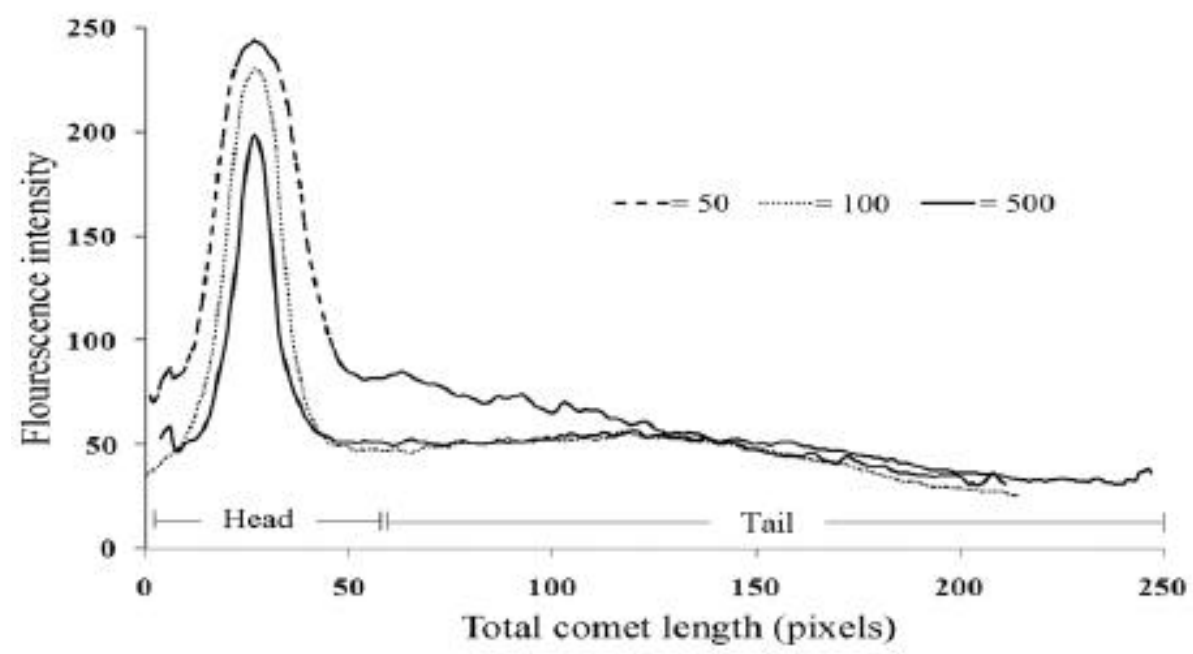

FIGURE 5. Fluorescence intensity profiles (range 0-255) of comets from spermatozoid nuclei exposed to hydrogen peroxide $\left(50,100\right.$ and $\left.500 \mu \mathrm{M} \mathrm{H}_{2} \mathrm{O}_{2}\right)$.

Figura 5. Perfiles de intensidad de fluorescencia (rango 0-255) en cometas de núcleos de espermatozoides expuestos a peróxido de hidrógeno $\left(50,100\right.$ y $500 \mu \mathrm{M} \mathrm{H}_{2} \mathrm{O}_{2}$ ).

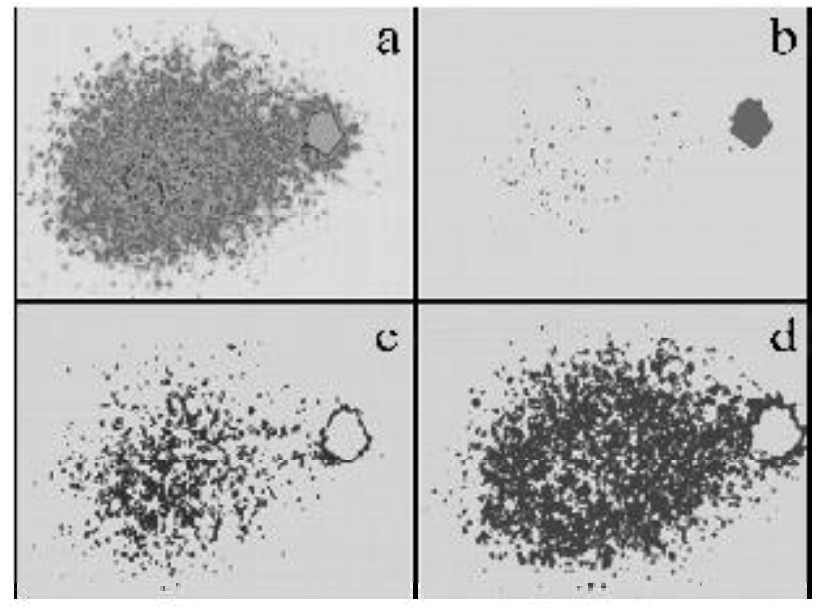

FIGURE 6. Fluorescence image analysis of DNA strand break size. a) Comet assay of nucleus sperm, ( b, c, d) segmentation of large, medium and small fragments, respectivelly.

FiguRA 6. Análisis de imágenes fluorescentes de tamaños de fragmentos de ADN. a) Ensayo cometa de núcleos espermáticos, (b, c, d) segmentación de fragmentos grandes, medianos y pequeños, respectivamente.

Sperm DNA is complex with basic proteins enabling its high degree of packing within spermatozoon head, up to some times more condensed than in somatic cells. Whereas, established an efficient electrophoresis time is more related to obtain a welldefined comet, in terms of distinguish clearly the nuclei (head) and tail form of it. We were able to assess that too much time of electrophoresis (> 30 min) can not discriminate damage using parameters as tail length and tail moment as it was difficult to determinate the real area corresponding to the tail (data not show). 


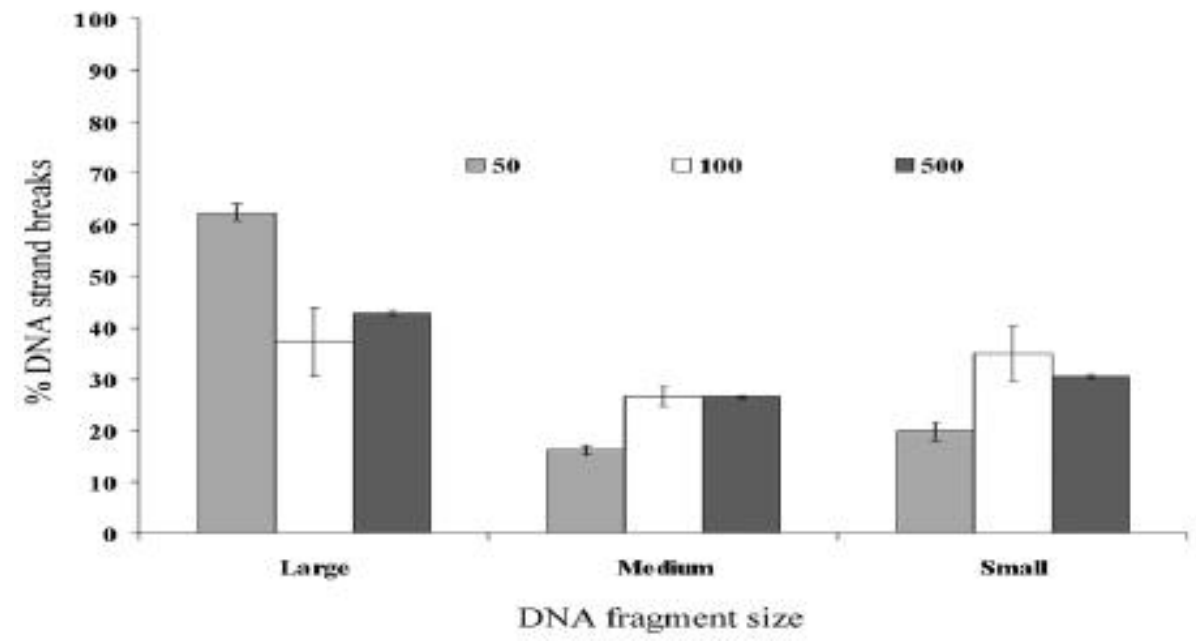

FIGURE 7. Percentages of DNA strand breaks (large, medium and small fragments) in spermatozoid nuclei exposed to hydrogen peroxide $(50,100$ and $500 \mu \mathrm{M})$.

FIGURA 7. Porcentajes de fragmentación de ADN (fragmentos grandes, medianos y pequeños) en núcleos de espermatozoides expuestos al peróxido de hidrógeno $(50,100$ y $500 \mu \mathrm{M})$.

Sperm sensitivity to $\mathrm{H}_{2} \mathrm{O}_{2}$ dose

Hydrogen peroxide causes DNA strand breakage by the generation of hydroxyl radical $(\mathrm{OH} \bullet)$ close to a DNA molecule via the Fenton reaction (Henle \& Linn 1997). Exposure of DNA to oxidative stress leads to more than 20 different types of base damage, producing oxidized and ring-fragmented nitrogen bases (Slupphaung et al. 2003). So, hydrogen peroxide is routinely used as positive control for comet assay analysis (Dietrich et al. 2005; Machella et al. 2006). The positive response to oxidative damage induced by $\mathrm{H}_{2} \mathrm{O}_{2}$ as been assessed in bivalve organisms as the common cockle Cerastoderma edule and common blue mussel M. edulis using gills cells and hemocytes as target cells (Wilson et al 1998; Cheung et al, 2006). In the other hand, sperm sensitivity response to other chemical and physical agents as copper and UV light has been determined in M. edulis (Steinert 1996). Copper treatment $(0-3 \mu \mathrm{M})$ had no influence on sperm DNA damage levels; while greater periods of UV exposure (0-10 $\mathrm{min})$ resulted in a linear increase in strand breaks. Besides the relevance of using mollusks spermatozoids as target cells to evaluated sperm quality and consequently with reproductive success, they also present some advantages over other kind of somatic cells commonly used in genotoxicity studies. Digestive gland cells, gill cells and hemocytes can present a basal DNA damage induced by isolation procedures and some comet assay protocol conditions, than can result in an over estimation of DNA damage (Machella et al. 2006). Where as collection of sperm is easily attain by manual stripping and, because its motility ability only competent spermatozoids can be taken (sampling just from the water column) and used for the assay. Although, further investigations have to be conduct to compare sensitivity among diverse cell types.

\section{Image analysis}

In initial studies, significance increases in the frequency of cells with damaged DNA were found in mussels with greater exposure to contaminants (Steinert et al. 1998). This was the first approach to quantify DNA damage, as percentage of damage cells. Later, the measures of comet morphology features as tail length, tail width, length:width ratios and nuclear diameter, were related to the level of DNA damage. But more recently, the use of image analysis allows us to obtain more information from comets, as total comet area, tail and head area among others. Used to calculated parameters as \% DNA tail, Olive tail moment, tail moment (Lee and Steinert 2003; Dietrichet al. 2005) and establish empirical scores classifying cells against observed damage. As Wilson et al. (1998) did categorizing damage scoring cells based on arbitrary establish ranges of \% DNA in tail. Or as the visual scoring to calculate an index of total damage (sum of percentage of comets in various classes from 1 to 5 , 
multiplied by the number of class) used and validated against tail length by Machella et al. (2006).

\section{CONCLUSION}

Comet assay procedure permits the detection of sperm DNA damage of the giant mussel Choromytilus chorus. Using this assay we have demonstrated a dose-response relationship between the level of DNA strand breaks (fragmentation) and concentrations of $\mathrm{H}_{2} \mathrm{O}_{2}$, as an oxidative agent. In the other hand, the new approach of fluorescence image analysis proposed in this study, allowed us to get more information and to improve the interpretation of results from sperm comets. And, although sperm quality of mollusks, measure as DNA integrity, can be done by comet assay, more studies are needed to discern sensitivities among diverse mollusks species of economical importance and to evaluate reproductive management strategies in aquaculture hatcheries facilities, as sperm preservation by cryopreservation or/and sperm inactivation by induced parthenogenesis (gynogenesis) with UV irradiation.

\section{ACKNOWLEDGMENTS}

We gratefully acknowledge CONACYT-México for the doctoral scholarship number 117673 assigned to Fabiola Lafarga-De la Cruz. This project was financially supported by FONDEF D05i10246 y D06i1027.

\section{REFERENCES}

Cheung, V., M. H. Depledge, A. N. Jha. 2006. An evaluation of the relative sensitivity of two marine bivalve mollusc species using the comet assay. Mar. Environ. Res. 62: 301-305.
Cotelle, S., J. F. Férard. 1999. Comet Assay in Genetic Ecotoxicology: A Review. Environ. Mol. Mutagen. 34:246-255

Dietrich, G.J., A. Szpyrka, M. Wojtczak, S. Dobosz, K. GorycZKo,L.Z AKowsKi, A. CIERESZKo. 2005. Effects of UV irradiation and hydrogen peroxide on DNA fragmentation, motility and fertilizing ability of rainbow trout (Oncorhynchus mykiss) spermatozoa. Theriogenology, 64:1809-1822

Henle, E. S., S. Linn. 1997. Formation, prevention, and repair of DNA damage by Iron/Hydrogen peroxide. Biol. Chem., 272 (31):19095-19098.

Lee, R.F., S. Steinert. 2003. Use of the single cell gel electrophoresis/comet assay for detecting DNA damage in aquatic (marine and freshwater) animals. Mutat. Res. 544 43-64.

M achella, N., M. Battino, B. Pisanelli, F. Regoli. 2006. Influence of the SCGE Protocol on the amount of basal DNA damage detected in the Mediterranean Mussel, Mytilus galloprovincialis. Environ. Mol. Mutag., 47:579-586.

Mitchelmore, C. L., C. Birmelin, D. R. Livingstone, J. K. Chipman. 1998. Detection of DNA strand breaks in isolated mussel (Mytilus edulis L.) digestive gland cells using the "comet assay". Ecotoxicol. Environ. Safety 41: 51-58.

Mitchelmore, C. L., J. K. Chipman. 1998. DNA strand breakage in aquatic organisms and the potential value of the comet assay in environmental monitoring. Mutat. Res. 399: 135-147.

Slupphaug, G., B. Kavli, H. E. KroKan. 2003. The interacting pathways for prevention and repair of oxidative DNA damage. Mutat. Res., 531: 231-251.

SteInerT, S. A., 1996. Contribution of apoptosis to observed DNA damage in mussel cells. Mar. Environ. Res, 42:253-259.

SteineRT, S. A. 1999. DNA damage as a bivalve biomarker. Biomarkers, 4(6): 492-496.

Steinert, S. A., R. Streib-Montee, J. M. Leather, D. B. CHADWICK. 1998. DNA Damage in mussels at sites in San Diego Bay. Mutat. Res., 399: 65-85.

Wilson, J. T., P.L. PASCOE, J. M. PARRY, D. R. Dixon. 1998. Evaluation of the comet assay as a method for the detection of DNA damage in the cells of a marine invertebrate, Mytilus edulis L. (Mollusca: Pelecypoda). Mutat. Res. 399: 87-95. 